\title{
The Rise of Temporary Work in Europe
}

\author{
Bas ter Weel ${ }^{1}$ \\ Published online: 22 October 2018 \\ (c) Springer Science+Business Media, LLC, part of Springer Nature 2018
}

Employment rates are back at pre-crisis levels in most European Union countries. In most countries employment is currently higher than before the great recession. Notable exceptions are Spain and Greece where the employment rate in 2017 is still more than 5\% points below its 2006 level. In the large EU-economies France and Germany the post-crisis employment rates are higher than before the crisis. Also in Sweden and the Netherlands the employment rate in 2017 is above the rate in 2006. This suggests that in most countries the labour market has recovered from the great recession when GDP growth improved-e.g., Van Ours (2015).

The composition of the employment rate recovery is different across countries, with more workers on temporary employment contracts in some countries than in others. The incidence of temporary employment has increased in for example France, Italy and the Netherlands. In the Netherlands, Poland, Portugal and Spain the incidence of temporary work is the highest in Europe with rates between 21 and $27 \%$ of the working age population. Sweden and Finland have more or less constant rates of temporary employment of about $16 \%$. Across the whole of the OECD countries, the incidence of temporary employment is relatively stable with about $11.5 \%$ of the working age population working on temporary contracts.

The causes of a rise in the incidence of temporary contracts and non-standard work arrangements have been discussed carefully in the economic literature. For example, a special issue of De Economist in 2012 focused on the nature and roles of the different types of labour contracts in the labour market (Cörvers et al. 2012). The issue discussed the difference in protection of permanent and temporary jobs, the adaptability of the economy, investments in skills and knowledge and workers' wages. The present collection of papers adds career prospects of those who work in non-standard jobs.

Technological change has induced a division of labour which is much more detailed than a couple of decades ago. Workers provide services through online intermediaries and sell goods and services directly to other consumers (Katz and Krueger 2017; Ter Weel et al. 2018). This influences the nature of work in modern economies. Although the share of workers who are involved in such activities is currently low (about

\footnotetext{
$\triangle \quad$ Bas ter Weel

b.terweel@seo.nl

1 SEO Amsterdam Economics, University of Amsterdam, Amsterdam, The Netherlands
} 
$0.5-2.5 \%$ of all workers), it is a new form of flexible work that is both supply-side induced, by a greater preference for alternative work arrangements, and demand-side fostered, by growing efficiency gains to contracting out activities that used to be core to the firm. Weil (2014) argues that competitive pressures have increased firm demands for flexibility and are causing a fissuring of the workplace, with workers increasingly being classified as contract employees and work being redefined to make greater use of contract workers and independent contractors (see also Akçomak et al. 2011).

Labour-market institutions in Europe have not adapted very well to changes in worker preferences and firms' demand for flexibility. In the aftermath of the crisis some measures have been taken, but contracts are increasingly flexible offering lower levels of protection, while the share of non-standard forms of work, including selfemployment, has risen rapidly. An increasing number of workers are no longer covered for sickness and disability risks, while in many countries tax incentives are promoting further migration to self-employment. The result is a larger share of workers on nonstandard contracts, an issue reviewed in greater debt by for example Boeri (2011) and Boeri and Van Ours (2013).

\section{Five Examples}

The present issue of De Economist is dedicated to the rise in temporary employment relations in Europe. The papers have been presented at a workshop about non-standard employment in The Hague. The workshop was organised by the CPB Netherlands Bureau for Economic Policy Analysis in the fall of 2016. The issue provides empirical insight in five European labour markets, each of which have seen an increase in the rise of flexible work arrangements and fixed-contracts for an increasing share of workers. The European labour markets discussed in this issue are Nordic (Sweden), continental European (the Netherlands and France) and Southern European (Spain and Italy).

Bolhaar et al. (2018) document and interpret trends in different types of employment contracts in the Netherlands since the early 2000s. They explain the rise in flexible employment contracts from an institutional point of view and discuss preferences for labour demand of firms and preferences for work among workers. They observe that younger workers often start with a fixed-term employment contract because firms want to screen their human capital potential. After a while some workers are offered a permanent contract, but this share has been falling over time. They also document that firms use fixed-term contracts to deal with changes in demand. To accommodate volatility of production and product demand risk, possibly due to globalization and technological change, the demand for labour has become more flexible over time. Especially younger workers and relatively low-skilled workers are more likely to work on fixed-term contracts. Third, their findings suggest that worker preferences for flexibility are especially large among younger and older workers. Younger workers prefer stepping-stone jobs, while older workers seem to prefer own-account work. These preferences however are unable to explain a substantial fraction of the rise in fixed-term employment in the Dutch labour market (e.g., De Graaf-Zijl et al. 2011). Finally, their findings suggest that institutions matter most for the rise in several types of flexible work arrangements in the Netherlands. For firms it is more expensive to hire 
workers on a permanent contract because of strict employment protection legislation (especially when compared to the protection of fixed-term workers) and other costs associated with permanent contracts. For workers, tax incentives make it tempting to become self-employed or to work as an own-account worker. This suggests that institutional incentives are such that both labour demand and a substantial part of labour supply are inclined to choose for flexible employment relationships.

Skedinger (2018) complements the analyses of Bolhaar et al. (2018) by investigating marginal labour-market groups in Sweden. He first investigates the employment rate of full-time workers who are employed on permanent contracts thereby paying special attention to the labour-market position of female workers and foreign born employees (often seen as 'marginal groups' in the Swedish labour market). The analysis in the paper continues by investigating the transition rates from fixed-term to permanent contracts and the wage differentials between fixed-term and permanent contracts. There seems to be evidence in favour of the stepping-stone hypothesis in the sense that there is a substantial transition rate from fixed-term to permanent contracts. This rate is lower for foreign born workers and females who are more likely to work for longer periods on fixed-term contracts. Finally, the wage differential between fixed-term and permanent contracts is negative and statistically significant, which is consistent with findings in other countries. However, the size of the wage differential is relatively low which is attributed to the compressed wage structure in Sweden and Nordic countries in general, a finding also documented earlier by for example Holmlund and Storrie (2002) for the period before 2000. Overall, the estimates suggest that workers who are employed on fixed-term contracts in Sweden seem to have better labour-market prospects in the sense of upward mobility and wages compared to those workers in the Netherlands.

Berson (2018) investigates the labour-market position of French workers in a similar way as Skedinger (2018) does for Sweden. She also distinguishes workers who are employed on fixed-term and permanent contracts. It seems to be the case that the labour market in France is more segmented compared to Sweden. Labour-market duality seems to be important because transition rates from fixed-term to permanent contracts are relatively low and the labour-market conditions between the two types of contracts are substantially different in favour of those workers who are employed on permanent contracts. Similar to the Netherlands, employment protection legislation seems to play an important role in explaining this difference between workers. Cahuc et al. (2016) show that lower rates of employment protection of permanent contracts leads to a significant substitution of fixed-term employment for permanent employment. This decreases duality and improves the opportunities of groups who are now working on fixed-term contracts for relatively long periods of time.

The findings in the paper of Berson (2018) show that almost $90 \%$ of all new hires are workers who start on fixed-term contracts, although the total share of fixed-term employment is only $12 \%$. This suggests that not only the incidence is high but that the duration of fixed-term contracts is short (and becoming increasingly shorter), feature also document in Felgueroso et al. (2018) for Spain. This trend has negative consequences for employer investments in human capital, which has become visible in lower rates of on-the-job training among workers who are employed on fixed-term contracts. The characteristics of French workers on fixed-term contracts are the following: they 
are more likely to be young, migrant and female and receive lower wages. This finding is consistent with the descriptive statistics and estimated coefficients for Sweden and the Netherlands. It reveals that relatively vulnerable workers receive lower rates of protection than is likely to be socially optimal in the long run in terms of more stable employment opportunities and human capital investments.

The final two papers investigate the labour-market situation of workers in Italy and Spain. In these countries labour-market duality seems to be even stronger than in countries such as France, Sweden and the Netherlands (e.g., Bentolila et al. 2012). The two contributions focus on the transition from temporary to permanent employment contracts and wages. Barbieri and Cutuli (2018) analyse the Italian labour market in the period 2004-2014 and find that temporary employment serves as a screening tool to dismiss the least productive workers rather than as a device to select the most productive workers. This suggests that a pool of workers faces a hard time to find stable employment opportunities. Workers employed on fixed-term contracts are more likely to be low-wage workers, with a remarkable concentration of such workers in the first decile of the wage distribution. The wage differential between workers on fixed-term and permanent contracts is highest in the lowest deciles of the wage distribution and the transition rate to permanent contracts is very low. Compared to France labour-market duality seems to be stronger with relatively high wage penalties for those workers with fixed-term contracts.

Felgueroso et al. (2018) document a new form of fixed-term employment in Spain: contracts with very short durations. Over the last decade both the fixed-term contracts with the longest durations (above 3 months) and the temporary contracts without a predetermined termination date have lost weight as in France. In general, the authors document an increase in the number of short-duration contracts: about a quarter of all new contracts lasts less than a week and about $40 \%$ of all new contracts lasts less than a month. Most of the new contracts concern recalls, which increases income volatility and lower job security. The empirical approach is to estimate hazard rates for the probability to transition from temporary to permanent work. The estimated coefficients suggest that the likelihood of temporary employment increases when workers have been worker on very short-term contracts in the past. Also, the rise in the mean number of temporary contracts for each worker and the increase in the mean time period until the first permanent contract seems to be driven by the pool temporary employees, suggesting a self-enforcing mechanism of labour-market duality. Together these two papers about Southern European labour markets show that there has been a rise in the share of fixed-term contracts over the last decade. This has led to a higher level of labour-market duality in an already segmented labour market, with fewer opportunities for permanent employment and income stability among especially young workers and workers with relatively low levels of productivity.

\section{References}

Akçomak, I. S., Borghans, L., \& ter Weel, B. (2011). Measuring and interpreting trends in the division of labour in the Netherlands. De Economist, 159(4), 435-482. 
Barbieri, P., \& Cutuli, G. (2018). Dual labour market intermediaries in Italy: How to lay off "lemons"-Thereby creating a problem of adverse selection. De Economist. https://doi.org/10.1007/s10645018-9324-0.

Bentolila, S., Cahuc, P., Dolado, J. J., \& Le Barbanchon, T. (2012). Two-tier labour markets in the great recession: France versus Spain. Economic Journal, 122(562), F155-F187.

Berson, C. (2018). Fixed-term contracts and labour market duality in France. De Economist. https://doi.or g/10.1007/s10645-018-9318-y.

Boeri, T. (2011). Institutional reforms and dualism in European labor markets. In O. Ashenfelter \& D. Card (Eds.), Handbook of labor economics (Vol. 4b, pp. 1173-1236). Amsterdam: North Holland.

Boeri, T., \& van Ours, J. C. (2013). The economics of imperfect labor markets. Princeton, NJ: Princeton University Press.

Bolhaar, J., de Graaf-Zijl, M., \& Scheer, B. (2018). Three perspectives on the Dutch growth of flexible employment. De Economist. https://doi.org/10.1007/s10645-018-9328-9.

Cahuc, P., Charlot, O., \& Malherbet, F. (2016). Explaining the spread of temporary jobs and its impact on labour turnover. International Economic Review, 57(5), 533-572.

Cörvers, F., Euwals, R., \& de Grip, A. (2012). Flexibility of the labour market. De Economist, 160(2), 83-87.

De Graaf-Zijl, M., van den Berg, G., \& Heyma, A. (2011). Stepping stones for the unemployed: The effect of temporary jobs on the duration until (regular) work. Journal of Population Economics, 24(1), 107-139.

Felgueroso, F., García-Pérez, J.-I., Jansen, M., \& Troncoso-Ponce, D. (2018). The surge in short-duration contracts in Spain. De Economist. https://doi.org/10.1007/s10645-018-9319-x.

Holmlund, B., \& Storrie, D. (2002). Temporary work in turbulent times: The Swedish experience. Economic Journal, 112(480), F245-F269.

Katz, L. F., \& Krueger, A. B. (2017). The role of unemployment in the rise of alternative work arrangements. American Economic Review, 107(5), 388-392.

Skedinger, P. (2018). Non-standard employment in Sweden. De Economist. https://doi.org/10.1007/s1064 5-018-9317-z.

Ter Weel, B., van der Werff, S., Bennaars, H., Scholte, R., Fijnje, J., Westerveld, M., et al. (2018). The rise and growth of the gig economy in the Netherlands. SEO report 2018-37, Amsterdam: SEO.

Van Ours, J. C. (2015). The great recession was not so great. Labour Economics, 34(1), 1-12.

Weil, D. (2014). The fissured workplace: Why work became so bad for so many and what can be done to improve it. Cambridge, MA: Harvard University Press. 